\title{
BACTERIOCINE-LIKE ACTIVITY OF GROUP-A STREPTO- COCCI DUE TO THE PRODUCTION OF PEROXIDE
}

\author{
H. Malke, Renate Starke, H. E. Jacob and W. KöhleR
}

Akademie der Wissenschaften der DDR, Forschungszentrum für Molekularbiologie und Medizin, Zentralinstitut für Mikrobiologie und experimentelle Therapie, Jena, Germany DDR

\section{Plates XV and XVI}

BACTERIOCINES represent a unique class of proteinaceous bactericidal substances that are produced by certain strains of bacteria and exhibit a narrow range of effectiveness against other strains of the same or closely related species (Nomura, 1967; Brandis and Šmarda, 1971; Reeves, 1972). Besides those on which a great amount of work has been done, there are others that are still poorly characterised; and there may even exist inhibitory phenomena that have mistakenly been attributed to the action of bacteriocines. The latter seems to be true of some antagonistic phenomena observed among group-A streptococci.

Sherwood et al. (1949) were among the first to report on the inhibitory action of certain streptococcal strains of various serological groups on other strains of streptococci. They named the inhibitory substance "streptostasin" without relating it to the class of substances later called bacteriocines. More recently, several investigators (Kuttner, 1966; Kolesnichenko, 1967; Overturf and Mortimer, 1970; Kolesnichenko and Totolyan, 1971; Totolyan and Kolesnichenko, 1971) have studied the production of antibacterial substances by group-A streptococci from the epidemiological point of view. These authors claimed that the inhibitory agents were bacteriocines, despite the fact that the respective substances had rather unusual properties. Thus, inhibitory activity was demonstrable on agar only when the producing and the indicator strain were growing actively. Cell-free filtrates or supernatant fluids from liquid cultures, as well as bacteria disintegrated by various means, were inactive; likewise, chloroformed cultures showed no activity. The inhibitory substances were insensitive to trypsin and were active against the homologous producer strain (Kuttner, 1966).

In this paper we present evidence to show that there exist inhibitory phenomena among group-A streptococci that are attributable to the toxic action of hydrogen peroxide produced by the test strains rather than to bacteriocine production.

\section{MATERIALS AND METHODS}

Strains. Representative group-A streptococcal strains of many different serotypes and from various sources were used in this study. Strains 5002 (type 2), 5003 (type 3R), 5004 (type 4), 5017 (type 17), 5019 (type 19), 5022 (type 22), 5023 (type 23), 5024 (type 24), 5025 (type 25), 5026 (type 26), 5027 (type 27), 5029 (type 29), 5030 (type 30), 5033 (type 33), 5034 
(type 34), 5036 (type 36), 5037 (type 37), 5038 (type 38), 5040 (type 40), 5041 (type 41), 5042 (type 42), 5043 (type 43), 5046 (type 46), 5047 (type 47), 5048 (type 48), 5049 (type 49), and 5050 (type 50) were obtained from R. C. Lancefield (Rockefeller University, New York, USA). Strains 5001 (type 1), 56188 (type 6), 5028 (type 28), and 5051 (type 51) came from W. R. Maxted (Cross-Infection Reference Laboratory, Colindale, London), A. E. Colón (National Institutes of Health, Bethesda, Md, USA), B. Perch (Statens Seruminstitut, Copenhagen, Denmark), and G. G. Wiley (DuPont Institute, Wilmington, Dela., USA), respectively. All the strain designations mentioned above are ours, and the original identification numbers of the strains are as given by Malke and Köhler (1973). Strains 1H (type 22), 152 (untyped), and 83 (untyped) were obtained from A. A. Totolyan (Institute for Experimental Medicine, Leningrad, USSR). Strains SM27 and SM60 are mutants sensitive to ultraviolet irradiation isolated in this laboratory (Malke, 1970) from Kjems' strain K56 (type 12).

Media. Liquid-medium cultures of indicator and test strains were grown in Brain-heart Infusion Broth (Difco) supplemented with Yeast Extract (Difco) $0.2 \%$ (w/v), DL-tryptophan $10 \mu \mathrm{g}$ per ml, $10^{-4} \mathrm{M} \mathrm{CaCl}_{2}$ (Friend and Slade, 1966), and horse serum $10 \%(\mathrm{v} / \mathrm{v})$. Solid medium for the detection of inhibitory phenomena was prepared by the addition of agar $1 \%(\mathrm{w} / \mathrm{v})$ and horse serum $2 \%(\mathrm{v} / \mathrm{v})$ to the above liquid medium. Heated blood (" chocolate ") agar for the detection of peroxide formation was made by adding horse blood $15 \%$ (v/v) to molten brain-heart infusion agar from which the serum was omitted. The mixture was heated for $15 \mathrm{~min}$. at $75^{\circ} \mathrm{C}$ and then poured into dishes (McLeod and Gordon, 1923b). Quantitative determination of peroxide formation was performed with cultures grown in beef-heart infusion broth supplemented with Proteose Peptone no. 2 (Difco) $10 \mathrm{~g}, \mathrm{NaCl} 3 \mathrm{~g}$, $\mathrm{Na}_{2} \mathrm{HPO}_{4} \cdot 12 \mathrm{H}_{2} \mathrm{O} 2 \mathrm{~g}, \mathrm{CaCl}_{2} 0.2 \mathrm{~g}$, glucose $1 \mathrm{~g}$, and horse serum $100 \mathrm{ml}$ per litre; $p \mathrm{H} 7 \cdot 2$ (Malke, 1969).

Chemicals. Catalase (at least 2000 units per mg according to Bergmeyer) from Reanal, Budapest, Hungary; trypsin (twice crystallised) from Spofa, Prague, Czechoslovakia; benzidine (A.R.) from Berlin-Chemie, Berlin, DDR; hydrogen peroxide (A.R.) from Orbiplast, Eilenburg, DDR.

Detection of inhibitory phenomena on solid medium. With slight modifications, the basic procedure employed for the detection of bacteriocine-like activity was a "simultaneous antagonism" method close to the drop-plate method of Kuttner (1966) and Overturf and Mortimer (1970). Overnight liquid cultures of the strains to be used as indicators (lawn strains) were diluted $5 \times 10^{4}$-fold in broth and $2 \cdot 0-\mathrm{ml}$ volumes of these dilutions were placed on the agar plates. After evenly covering the surface of the plates with the bacterial suspensions, the excess fluid was removed and the plates were incubated for $20 \mathrm{~min}$. at $37^{\circ} \mathrm{C}$. When dry, 5- to 10- $\mu \mathrm{l}$ volumes of overnight cultures of the strains to be tested for antibacterial activity were dropped on the indicator lawns. Plates were incubated overnight at $37^{\circ} \mathrm{C}$ before being examined for the presence of inhibition zones.

As a second method, the technique of "deferred antagonism " according to Tagg, Read and McGiven (1973) was used. Loopfuls of overnight test cultures were streaked on agar plates. After incubation for 18 hours at $37^{\circ} \mathrm{C}$, the growth was removed with a glass slide and the agar surface exposed to chloroform vapour for $30 \mathrm{~min}$. Overnight cultures of the strains to be used as indicators were diluted 100 -fold in fresh broth, incubated for $30 \mathrm{~min}$. at $37^{\circ} \mathrm{C}$ and then cross-streaked to the line of the test strain. After incubation for 18 hours at $37^{\circ} \mathrm{C}$ the plates were examined for inhibition of indicator growth in the vicinity of the teststrain line.

Incubation under anaerobic conditions was performed in a desiccator in which the air had been replaced by nitrogen. The effect of catalase and trypsin on the formation of inhibition zones was studied by supplementing the agar medium with 0.125 to 500 units of catalase or $200 \mu \mathrm{g}$ of trypsin per $\mathrm{ml}$.

Detection of peroxide formation. Peroxide formation was detected qualitatively by placing drops of overnight cultures grown in supplemented brain-heart infusion broth on heated blood-agar plates (McLeod, Gordon and Pyrah, 1923). After overnight incubation at $37^{\circ} \mathrm{C}$, peroxide producers gave rise to a green discoloration of this medium. Alternatively, 
an alcoholic solution of benzidine was poured over the surface of ordinary blood-agar plates and allowed to dry (Fuller and Maxted, 1939). On this medium, colonies of peroxide formers appeared bluish-black. The failure of peroxide producers to give a positive reaction on heated blood or benzidine agar when incubated anaerobically or in the presence of catalase was taken as evidence for the specificity of the test.

Quantitative determination of hydrogen peroxide. Polarographic methods can with advantage be used for the direct determination of $\mathrm{H}_{2} \mathrm{O}_{2}$ in turbid liquid cultures of bacteria (Jacob, 1964). Flasks containing $5 \mathrm{ml}$ of supplemented beef-heart infusion broth were seeded with loopfuls of overnight cultures, inserted into a gyratory shaker, and rotated at 240 r.p.m. for 16 hours at $37^{\circ} \mathrm{C}$. The bacterial suspensions were then transferred to a polarographic cell devised by Berg (1955) and de-aerated by bubbling argon through the cell. The $\mathrm{H}_{2} \mathrm{O}_{2}$ concentration was measured at $25^{\circ} \mathrm{C}$ on the polarograph $\mathrm{OH} 102$ (Radelkis, Budapest, Hungary) by the automatic recording of the current-voltage curves at a potential ranging from zero to $-1.8 \mathrm{~V}$, obtained by means of the mercury-drop cathode and the standard calomel electrode. Calibration curves obtained by polarographic measurement of standard $\mathrm{H}_{2} \mathrm{O}_{2}$ solutions made in the culture medium served to relate the polarographic wave heights given by the test cultures to absolute $\mathrm{H}_{2} \mathrm{O}_{2}$ concentrations. Treatment of the bacterial suspensions with catalase (c. 500 units per $\mathrm{ml}$ for $10 \mathrm{~min}$.) led to the disappearance of the polarographic $\mathrm{H}_{2} \mathrm{O}_{2}$ wave.

\section{RESULTS}

The table summarises the results of testing by the " simultaneous antagonism " method of the 36 strains, each of which was used not only as test but also as indicator strain. Of these strains, $28(78 \%)$ consistently produced distinct inhibition zones on a variety of different indicator lawns when tested under aerobic conditions. Contrary to the observation of Kuttner (1966), strains suitable to serve as indicators were rather common, and therefore individual antagonistic pairs need not be specified. It should be noted, however, that nos. 5001, 5002, 5003, 5004, 5019, and 5026 were particularly good lawn strains because they were susceptible to the great majority of the test strains and also tended to show large and clear inhibition zones. With few exceptions (nos. $5023,5048)$, all strains exhibiting antagonistic effects did so also when tested against themselves in homologous assays. Of the eight strains that gave a negative result in the drop assay, nos. 5001, 5003, 5017, and 5050 behaved in this way towards all indicators whenever tested. The remaining four strains described as negative showed a weak inhibitory effect when first tested but were negative on retesting one year later. A similar variability in the production of inhibition zones by some strains was noted by Kuttner (1966) and Overturf and Mortimer (1970). A limited number of tests was performed with cell-free filtrates of unaerated overnight cultures but, in agreement with the observations of Kuttner (1966), in no case could any inhibitory activity be detected that could be attributed to agents other than bacteriophages. Also, strains used as indicators were tested for their sensitivity to hydrogen peroxide in the drop assay and in all cases showed growth inhibition when treated with a solution of at least $0.5 \% \mathrm{H}_{2} \mathrm{O}_{2}$ (see figs. 1 and 2).

In contrast, the technique of deferred antagonism failed to reveal any inhibitory effects although each of the 36 strains was tested in all possible paired combinations.

To investigate the nature of the agent causing growth inhibition of the lawn 
strains, the ordinary drop assay was modified by incorporating trypsin or catalase into the agar medium, or by incubating the test plates under anaerobic

\section{TABLE}

Inhibitory action and peroxide formation under various conditions by 36 group-A streptococcal strains. The strains are listed according to decreasing $\mathrm{H}_{2} \mathrm{O}_{2}$ concentrations in liquidmedium cultures

\begin{tabular}{|c|c|c|c|c|c|c|c|c|}
\hline \multirow[b]{2}{*}{$\begin{array}{c}\text { Number of } \\
\text { test } \\
\text { strain }\end{array}$} & \multicolumn{4}{|c|}{ Formation of inhibition zones (drop-plate method) } & \multicolumn{3}{|c|}{ Peroxide test on heated blood agar } & \multirow{2}{*}{$\begin{array}{c}\text { Formation of } \\
\text { peroxide during } \\
\text { overnight growth } \\
\text { in aerated liquid } \\
\text { cultures } \\
\text { (m.mol per } 1 \text { ) }\end{array}$} \\
\hline & $\begin{array}{c}\text { under } \\
\text { ordinary } \\
\text { conditions } \\
\text { (Kuttner test) }\end{array}$ & $\begin{array}{l}\text { in the } \\
\text { presence } \\
\text { of trypsin }\end{array}$ & $\begin{array}{c}\text { in the } \\
\text { presence } \\
\text { of catalase }\end{array}$ & $\begin{array}{c}\text { under } \\
\text { anaerobic } \\
\text { conditions }\end{array}$ & $\begin{array}{c}\text { under } \\
\text { ordinary } \\
\text { conditions }\end{array}$ & $\begin{array}{c}\text { in the } \\
\text { presence } \\
\text { of catalase }\end{array}$ & $\begin{array}{c}\text { under } \\
\text { anaerobic } \\
\text { conditions }\end{array}$ & \\
\hline $\begin{array}{l}\text { SM60 } \\
5038 \\
5022 \\
1 H \\
5024\end{array}$ & $\begin{array}{l}+(26 / 34)^{*} \\
+(31 / 34) \\
+(31 / 34) \\
+(4 / 4) \\
+(27 / 34)\end{array}$ & $\begin{array}{l}+(4 / 4) \\
+(5 / 5) \\
+(2 / 2) \\
+(1 / 1) \\
+(1 / 1)\end{array}$ & $\begin{array}{l}-(4 / 4) \\
=(5 / 5) \\
=(2 / 2) \\
-(1 / 1) \\
-(1 / 1)\end{array}$ & $\begin{array}{l}-(3 / 3) \\
-(5 / 5) \\
-(4 / 4) \\
\cdots\end{array}$ & $\begin{array}{l}+ \\
\pm \\
\pm\end{array}$ & $\begin{array}{l}\bar{z} \\
\bar{z} \\
\bar{z}\end{array}$ & $\begin{array}{l}\overline{-} \\
\bar{z} \\
-\end{array}$ & $\begin{array}{l}8.5 \\
8.5 \\
8 \cdot 0 \\
8 \cdot 0 \\
7 \cdot 5\end{array}$ \\
\hline $\begin{array}{l}5004 \\
56188 \\
83 \\
5036 \\
\text { SM27 }\end{array}$ & $\begin{array}{l}+(28 / 34) \\
+(34 / 34) \\
+(5 / 5) \\
+(27 / 34) \\
+(21 / 34)\end{array}$ & $\begin{array}{l}+(5 / 5) \\
+(5 / 5) \\
+(5 / 5) \\
+(4 / 4)\end{array}$ & $\begin{array}{l}-(5 / 5) \\
-(5 / 5) \\
-(5 / 5) \\
-(4 / 4)\end{array}$ & $\begin{array}{l}-(5 / 5) \\
-(5 / 5) \\
-(5 / 5) \\
-(5 / 5) \\
\ldots\end{array}$ & $\begin{array}{l}+ \\
+ \\
+ \\
+ \\
+\end{array}$ & $\begin{array}{l}\bar{z} \\
\bar{z}\end{array}$ & $\begin{array}{l}z \\
\bar{z} \\
=\end{array}$ & $\begin{array}{l}7.0 \\
7.0 \\
6.5 \\
6.5 \\
6.0\end{array}$ \\
\hline $\begin{array}{l}5019 \\
5023 \\
5049 \\
5029 \\
152\end{array}$ & $\begin{array}{l}+(27 / 34) \\
+(22 / 34) \\
+(25 / 34) \\
+(30 / 34) \\
+(4 / 4)\end{array}$ & $\begin{array}{l}+(3 / 3) \\
+(2 / 2) \\
+(2 / 2) \\
+(2 / 2) \\
+(1 / 1)\end{array}$ & $\begin{array}{l}-(3 / 3) \\
-(2 / 2) \\
-(3 / 3) \\
=(2 / 2) \\
-(1 / 1)\end{array}$ & $\begin{array}{c}\ldots \\
\ldots \\
-(4 / 4) \\
-(4 / 4)\end{array}$ & $\begin{array}{l}- \\
+ \\
+ \\
+ \\
+\end{array}$ & $\begin{array}{l}\bar{z} \\
=\end{array}$ & $\begin{array}{l}\overline{-} \\
\bar{z} \\
\overline{-}\end{array}$ & $\begin{array}{l}6.0 \\
6.0 \\
6.0 \\
5.5 \\
5.0\end{array}$ \\
\hline $\begin{array}{l}5026 \\
5027 \\
5033 \\
5041 \\
5043\end{array}$ & $\begin{array}{l}+(30 / 34) \\
+(30 / 34) \\
+(31 / 34) \\
+(29 / 34) \\
+(32 / 34)\end{array}$ & $\begin{array}{l}+(5 / 5) \\
+(3 / 3) \\
+(3 / 3) \\
+(4 / 4) \\
+(3 / 3)\end{array}$ & $\begin{array}{l}-(5 / 5) \\
-(3 / 3) \\
-(3 / 3) \\
-(4 / 4) \\
-(3 / 3)\end{array}$ & $\begin{array}{l}-(5 / 5) \\
-(4 / 4) \\
-(5 / 5) \\
-(4 / 4)\end{array}$ & $\begin{array}{l} \pm \\
+ \\
+ \\
+\end{array}$ & $\begin{array}{l}\bar{z} \\
\bar{z}\end{array}$ & $\begin{array}{l}\bar{z} \\
\bar{z}\end{array}$ & $\begin{array}{l}5.0 \\
4.5 \\
4 \cdot 5 \\
4.5 \\
4.5\end{array}$ \\
\hline $\begin{array}{l}5046 \\
5051 \\
5002 \\
5042 \\
5047\end{array}$ & $\begin{array}{l}+(32 / 34) \\
+(21 / 34) \\
+(29 / 34) \\
+(34 / 34) \\
+(23 / 34)\end{array}$ & $\begin{array}{l}+(4 / 4) \\
+(2 / 2) \\
+(5 / 5) \\
+(4 / 4) \\
+(1 / 1)\end{array}$ & $\begin{array}{l}-(3 / 3) \\
-(2 / 2) \\
-(5 / 5) \\
-(4 / 4) \\
-(3 / 3)\end{array}$ & $\begin{array}{c}-(5 / 5) \\
\ldots \\
-(3 / 3) \\
-(5 / 5) \\
\ldots\end{array}$ & $\begin{array}{l}+ \\
+ \\
+ \\
+\end{array}$ & $\begin{array}{l}\overline{-} \\
\bar{z}\end{array}$ & $\begin{array}{l}\bar{z} \\
\bar{z} \\
\overline{-}\end{array}$ & $\begin{array}{l}4 \cdot 0 \\
3 \cdot 5 \\
3 \cdot 0 \\
3 \cdot 0 \\
2.5\end{array}$ \\
\hline $\begin{array}{l}5030 \\
5037 \\
5040 \\
5028 \\
5048\end{array}$ & $\begin{array}{l}+(33 / 34) \\
-(29 / 29) \\
+(24 / 34) \\
-(30 / 30) \\
+(4 / 34)\end{array}$ & $\begin{array}{l}+(4 / 4) \\
-(5 / 5) \\
+(5 / 5) \\
-(4 / 4) \\
+(4 / 4)\end{array}$ & $\begin{array}{l}-(4 / 4) \\
-(5 / 5) \\
-\dddot{(3 / 3)}\end{array}$ & $\begin{array}{c}-(5 / 5) \\
-(4 / 4) \\
\ldots \\
\ldots\end{array}$ & $\begin{array}{l}\frac{+}{+} \\
\frac{ \pm}{+}\end{array}$ & $\begin{array}{l}\bar{z} \\
\bar{z}\end{array}$ & $\begin{array}{l}= \\
= \\
=\end{array}$ & $\begin{array}{l}2.0 \\
2.0 \\
1.0 \\
0.8 \\
0.5\end{array}$ \\
\hline $\begin{array}{l}5001 \\
5003 \\
5017 \\
5025 \\
5034 \\
5050\end{array}$ & $\begin{array}{l}-(34 / 34) \\
-(34 / 34) \\
-(34 / 34) \\
=(28 / 28) \\
=(15 / 15) \\
-(34 / 34)\end{array}$ & $\begin{array}{l}-(5 / 5) \\
=(5 / 5) \\
-(5 / 5) \\
=(5 / 5) \\
=(5 / 5) \\
-(5 / 5)\end{array}$ & $\begin{array}{l}\ldots \\
\ldots \\
\ldots \\
\ldots \\
\ldots\end{array}$ & $\begin{array}{l}\ldots \\
\ldots \\
\ldots \\
\ldots \\
\ldots\end{array}$ & $\begin{array}{l}z \\
= \\
=\end{array}$ & $\begin{array}{l}z \\
\bar{z} \\
\bar{z}\end{array}$ & $\begin{array}{l}\bar{z} \\
\bar{z} \\
\bar{z}\end{array}$ & $\begin{array}{l}<0.25 \\
<0.25 \\
<0.25 \\
<0.25 \\
<0.25 \\
<0.25\end{array}$ \\
\hline
\end{tabular}

$+=$ Present; $-=$ not present $; \ldots=$ not tested.

* Figures in parenthesis $=$ the number of indicator strains on which the indicated reaction occurred/total number of indicator strains tested.

conditions (table). In the presence of trypsin, which is known to destroy the activity of bacteriocines (Bradley, 1967), all strains characterised as antagonistic continued to produce inhibition zones in the Kuttner-type test. Conversely, the same strains failed to do so when tested in the presence of catalase or under anaerobiosis, i.e., conditions that abolished the formation of peroxide. To exclude the possibility that the effect of the catalase preparation was due to some component other than catalase itself, the enzyme, which was routinely present at a concentration of 500 units per $\mathrm{ml}$, was employed in two-fold dilutions to 
“BACteriocines" OF Group-A StREPTOCOCCI
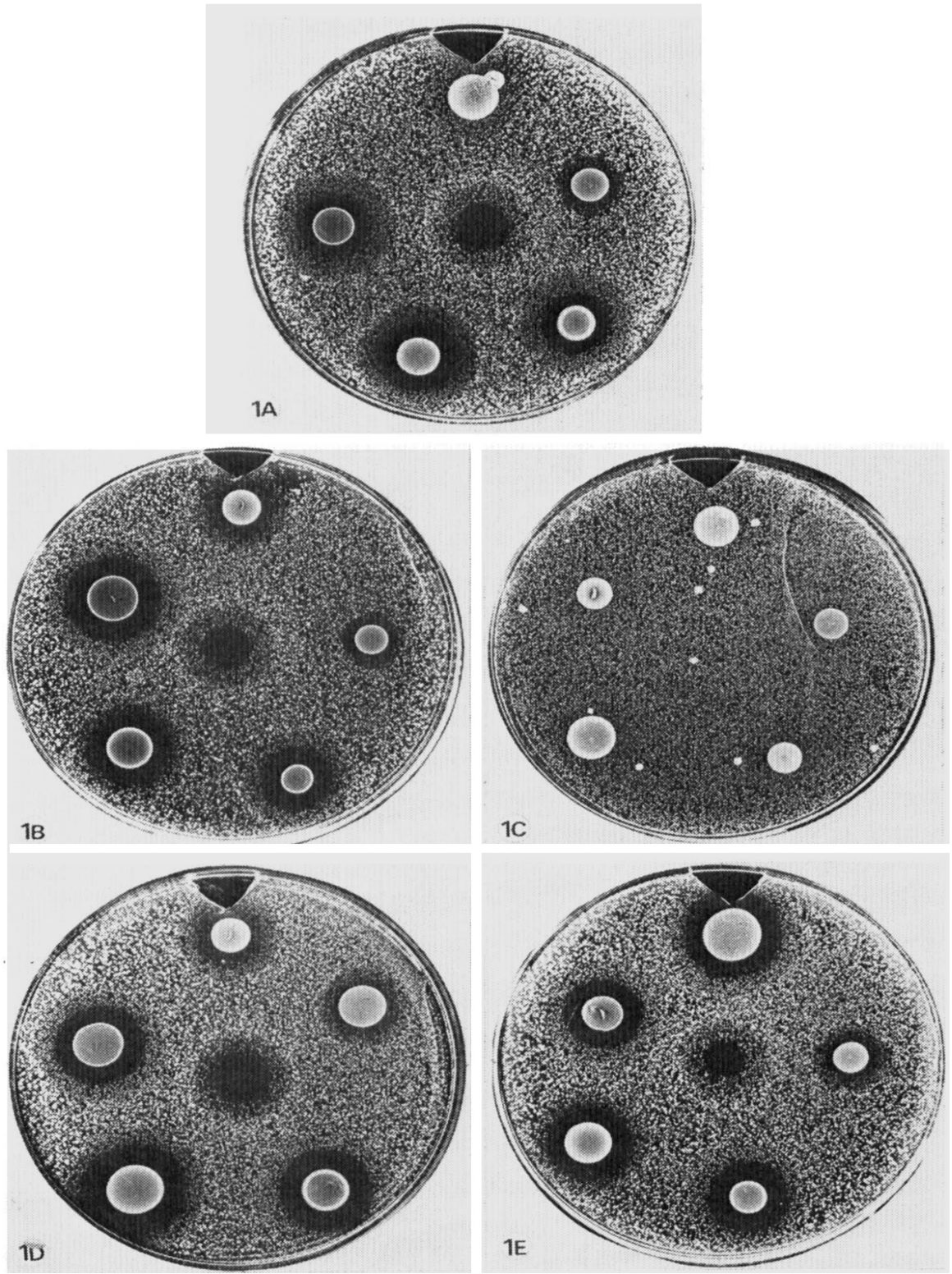

FIG. 1.-Drop-plate method for demonstrating growth inhibition of the indicator strain 5003 by peroxide produced by the test strains $1 \mathrm{H}, 152,5038,56188$, and 5004 (clockwise direction, starting at the punched triangle). A drop of a $0.5 \% \mathrm{H}_{2} \mathrm{O}_{2}$ solution was placed in the centre of each plate; $\mathrm{A}=$ under ordinary conditions; $\mathrm{B}-\mathrm{E}=$ in the presence of $200 \mu \mathrm{g}$ per $\mathrm{ml}$ of trypsin (B), 10 units per $\mathrm{ml}$ of catalase (C), 500 units per $\mathrm{ml}$ of heat-inactivated catalase (D), 500 units per $\mathrm{ml}$ of trypsin-digested catalase (E). 


\section{" BACTERIOCINES" OF GROUP-A STREPTOCOCCI}
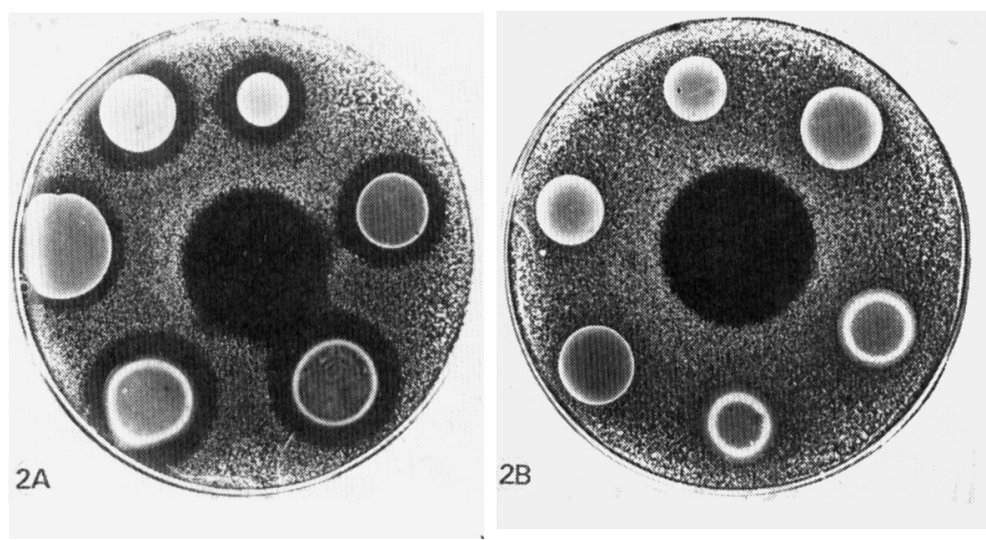

FIG. 2.-Effect of anaerobiosis on the formation oi inhibition zones on strain 5003 by the test strains $56188,5004,5026,5036,152$, and $1 \mathrm{H}$ (clockwise direction, starting at 12 o'clock). A drop of a $0.5 \% \mathrm{H}_{2} \mathrm{O}_{2}$ solution was placed in the centre of each plate; $A$ =incubated aerobically; $\mathrm{B}=$ incubated anaerobically. 
estimate the minimum concentration able to suppress the formation of inhibition zones. This was found to amount to approximately 1 unit per $\mathrm{ml}$ with strains $1 \mathrm{H}, 83,152,5004,5038,56188$, and SM27. Preparations of catalase, in aqueous solution containing 500 enzyme units per $\mathrm{ml}$, that had been heated at $100^{\circ} \mathrm{C}$ for a few seconds or had been incubated in the presence of trypsin (200 $\mu \mathrm{g}$ per $\mathrm{ml}$ ) for 24 hours at $37^{\circ} \mathrm{C}$ no longer interfered with the growthinhibiting activity of the test strains. A few results obtained with these variants of the basic procedure are illustrated in figs. 1 and 2 .

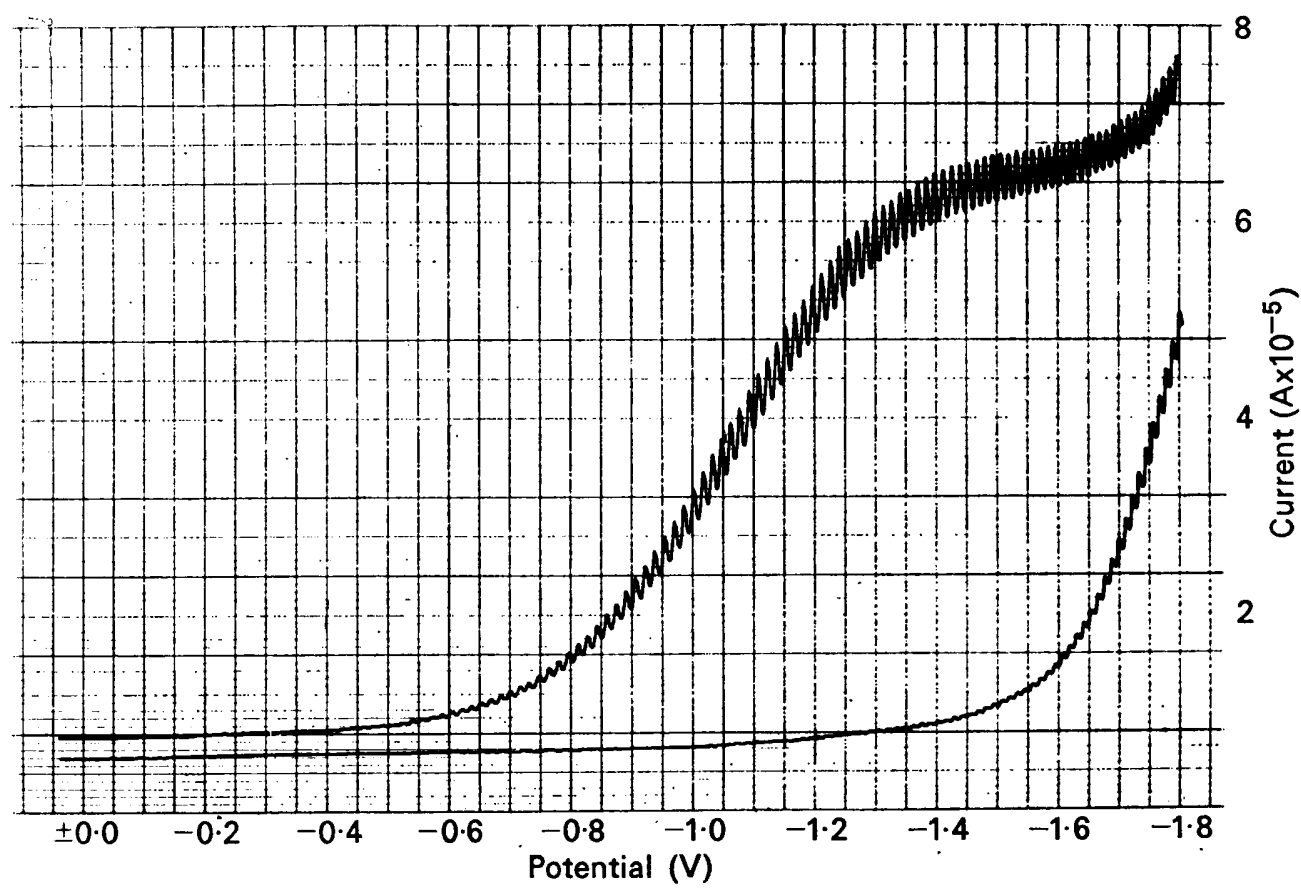

FIG. 3.-Polarographic records of current versus applied potential for measuring $\mathrm{H}_{2} \mathrm{O}_{2}$ in an aerated overnight culture of strain 5049 before (upper curve) and after treatment with catalase (lower curve).

Examination of the 36 strains under study for the formation of peroxide revealed that the majority of the strains characterised as antagonistic in the table gave a positive peroxide test on heated blood agar. The strains with no antibacterial activity were consistently negative in this test. The test for peroxide formation on benzidine agar was found to be less sensitive than that on chocolate agar. There was also some day-to-day variability in the results of the peroxide test on chocolate agar, but strains indicated as peroxide formers in the table gave a positive reaction in at least $33 \%$ of trials.

The results of the quantitative polarographic determination of hydrogen peroxide in aerated liquid cultures (fig. 3) corresponded well to the results of the biological testing of the strains. Thus, all strains with inhibitory activity were found to elaborate hydrogen peroxide in the culture medium, the amounts ranging from 0.5 to $8.5 \mathrm{~m} . \mathrm{mol}$. per 1 (table). These concentrations were 
remarkably high and could in some cases be shown to cause self-sterilisation of the cultures. Strains that failed to show inhibitory activity in the drop assay or behaved questionably in this test either failed to release detectable amounts of $\mathrm{H}_{2} \mathrm{O}_{2}$ or were rather poor peroxide producers (table).

\section{Discussion}

The clear-cut effects of trypsin, catalase and anaerobiosis on the bactericidal activity of the present strains lead inevitably to the conclusion that their antagonistic activity is attributable to the action of peroxide, which the cells are able to produce in ordinary test conditions, and that this activity has nothing to do with the action of bacteriocines. The properties of the antibacterial agent or agents reported by Kuttner (1966) do not rule out the possibility that the inhibitor was hydrogen peroxide. Because the present strains (except nos. $1 \mathrm{H}$, 83 , and 152) are not identical with those tested by the supporters of the bacteriocine hypothesis, we cannot definitely prove that our conclusion also applies to their strains. In view of the wide distribution of peroxide formers among group-A streptococci (McLeod and Gordon, 1923a; Fuller and Maxted, 1939; Rosebury, Gale and Taylor, 1954; Noble and Vosti, 1971; the table) and the fact that Kuttner (1966), Kolesnichenko (1967), Overturf and Mortimer (1970), Kolesnichenko and Totolyan (1971) and Totolyan and Kolesnichenko (1971) performed their tests under conditions that did not exclude the action of peroxide, the question of whether they really encountered bacteriocines remains open. In the studies of the aforementioned workers, the frequency of antagonistic strains among the total strains tested ranged from $50 \%$ to nearly $100 \%$. The percentage of peroxide producers in the present study is of the same order of magnitude, lending further support to the view that peroxide is the principal factor causing growth inhibition in the drop-plate method. From this viewpoint it does not seem to be merely coincidental that type-3 streptococci, which differ from other serotypes of group A in not producing peroxide (Fuller and Maxted, 1939), were also without inhibitory activity in the study of Overturf and Mortimer (1970). It thus appears that the only antibacterial substance formed by group-A streptococci that has been characterised sufficiently well for it to be considered a bacteriocine is that recently described by Tagg et al. (1973), who report the agent to be sensitive to proteolytic enzymes and produced under both aerobic and anaerobic conditions as well as in the presence of a source of catalase.

After these experiments had been completed, we saw a paper by Holmberg and Hallander (1973), who showed that the bacteriocine-like activity of certain strains of Streptococcus sanguis (group H) is due to the liberation of peroxide.

\section{SUMMARY}

The drop-plate method of " simultaneous antagonism" used by others for the detection of bacteriocinogeny in group-A streptococci is unsuitable to differentiate the inhibitory action of true bacteriocines from that of peroxide produced by the test strains. Among 36 group-A streptococcal strains examined, 
$78 \%$ displayed inhibitory activity on appropriate indicator strains but failed to do so when tested under anaerobic conditions or in the presence of catalase. Most of these strains were shown to give a positive peroxide test on heated blood agar, all of them released hydrogen peroxide during growth in aerated liquid cultures as measured quantitatively by polarography, and none of them lost its inhibitory effect in the presence of trypsin. No strains were encountered that, apart from bacteriophages, produced any catalase-stable, trypsin-sensitive inhibitory substances. For inhibitory effects to be considered to reflect the action of bacteriocines, it is therefore necessary to show that inhibition cannot be ascribed to the toxic effect of liberated peroxide.

\section{REFERENCES}

BeRG, H. 1955. Polarographische Frittenzellen. Chem. Technik, 7, 679.

BradLEY, D. E. 1967. Ultrastructure of bacteriophages and bacteriocins. Bact. Rev., 31, 230.

Brandis, H. AND ŠmaRdA, J. 1971. Bacteriocine und bacteriocinähnliche Substanzen, Jena.

Friend, P. L. AND Slade, H. D. 1966. Characteristics of group A streptococcal bacteriophages. J. Bact., 92, 148.

Fuller, A. T. AND MAXTED, W. R. 1939. A type of group A haemolytic streptococcus which fails to form peroxide. Br.J. exp. Path., $20,177$.

Holmberg, K. and Hallander, H. O. 1973. Production of bactericidal concentrations of hydrogen peroxide by Streptococcus sanguis. Archs oral Biol., 18, 423.

JACOB, H. E. 1964. Katalaseaktivitätsbestimmungen von Mikroorganismen mit Hilfe der Polarographie. Z. Chem., 4, 189.

KolesNichenKo, T. G. 1967. Bacteriocinogenic activity of hemolytic streptococci, group A. Zh. Mikrobiol. Epidem. Immunobiol., no. 12, 75.

Kolesnichenko, T. G. AND Totolyan, A. A. 1971. The distribution of bacteriocinogenesis among hemolytic streptococci of A group. Bull. exp. Biol. Med., no. 6, 65.

KutTner, A. G. 1966. Production of bacteriocins by group A streptococci with special reference to the nephritogenic types. J. exp. Med., 124, 279.

MCLEOD, J. W. AND GoRdon, J. 1923a. Catalase production and sensitiveness to hydrogen peroxide amongst bacteria, with a scheme of classification based on these properties. J. Path. Bact., 26, 326.

MCLEOD, J. W. AND GoRDON, J. 1923b. The problem of intolerance of oxygen by anaerobic bacteria. J. Path. Bact., 26, 332.

McLeod, J. W., Gordon, J. AND Pyrah, L. N. 1923. Further observations on peroxide formation by bacteria. J. Path. Bact., 26, 127.

MALKE, H. 1969. Transduction of Streptococcus pyogenes K56 by temperature-sensitive mutants of the transducing phage A25. Z. Naturf., 24b, 1556.

MALKE, H. 1970. Complementation between uvr mutants of Streptococcus pyogenes. Molec. gen. Genet., 109, 278.

MALKe, H. AND KöHLER, W. 1973. Transduction among group A streptococci: transducibility of strains representative of thirty different $\mathbf{M}$ types. Zentbl. Bakt.ParasitKde, I. Abt. Orig., 224, 194.

Noble, R. C. AND Vosti, K. 1971. Production of double zones of hemolysis by certain strains of hemolytic streptococci of group A, B, C, and G on heart infusion agar. Appl. Microbiol., 22, 171.

Nomura, M. 1967. Colicins and related bacteriocins. A. Rev. Microbiol., 21, 257.

Overturf, G. D. AND Mortimer, E. A. 1970. Studies of the relationship between the production of bacteriocins by group A streptococci and acute glomerulonephritis. J. exp. Med., 132, 694.

ReEves, P. 1972. The bacteriocins, Berlin, Heidelberg and New York. 
Rosebury, T., Gale, D. and TAYLoR, D. F. 1954. An approach to the study of interactive phenomena among microorganisms indigenous to man. J. Bact., 67, 135.

Sherwood, N. P., Russell, B. E., Jay, A. R. and Bowman, K. 1949. Studies on streptococci. III. New antibiotic substances produced by beta hemolytic streptococci. $J$. infect. Dis., 84, 88.

TAGG, J. R., ReAD, R. S. D. AND McGiven, A. R. 1973. Bacteriocin of a group A streptococcus: partial purification and properties. Antimicrob. Agents Chemother., 4, 214.

Totolyan, A. A. AND Kolesnichenko, T. G. 1971. Bacteriocinogenic properties of hemolytic streptococci, group A, of various serological types. Zh. Mikrobiol. Epidem. Immunobiol., no. 8, 70. 